\title{
Temperature-dependent expression of flagella in Legionella
}

\author{
Manfred Ott,${ }^{1 *}$ Paul Messner,,${ }^{2}$ JÜrgen Heesemann, ${ }^{3}$ Reinhard MarRe ${ }^{4}$ and \\ JÖRG HACKER ${ }^{1}$
}

${ }^{1}$ Institut für Genetik und Mikrobiologie, Universität Würzburg, Röntgenring 11, W-8700 Würzburg, Germany

${ }^{2}$ Zentrum für Ultrastrukturforschung und Ludwig Boltzmann-Institut für Ultrastrukturforschung, Universität für

Bodenkultur, A-1180 Wien, Austria

${ }^{3}$ Institut für Hygiene und Mikrobiologie, Universität Würzburg, Josef Schneider Strasse 2, W-8700 Würzburg, Germany

${ }^{4}$ Institut für Medizinische Mikrobiologie, Universität Lübeck, Ratzeburger Allee 160, W-2400 Lübeck, Germany

(Received 31 December 1990; revised 15 April 1991; accepted 29 April 1991)

\begin{abstract}
Legionella pneumophila, the causative agent of Legionnaires' disease, was analysed by electron microscopy for production of surface structures. Crystalline surface (S-) layers and fimbriae were not detected, but monotrichous flagellation was seen. Polyclonal antibodies specific for the $47 \mathrm{kDa}$ flagellin subunit of $L$. pneumophila Philadelphia I were used in Western blots to confirm the presence of flagella subunits in various $L$. pneumophila strains tested, but the antiserum also reacted with flagellin subunits of $L$. micdadei, $L$. hackelia |serogroup (SG) 1 and SG2] and L. longbeachae (SG2). Flagellation of Legionellae was shown to be temperature regulated. When the growth temperature of virulent and avirulent variants of strain $L$. pneumophila Philadelphia I was shifted from $30{ }^{\circ} \mathrm{C}$ to either 37 or $41^{\circ} \mathrm{C}$, a decrease in the percentage of flagellated bacteria within the population was observed.
\end{abstract}

\section{Introduction}

Legionella pneumophila, the aetiological agent of a severe pneumonia called Legionnaires' disease, is a Gramnegative rod-shaped bacterium which is able to multiply in lung macrophages (Winn, 1988; Cianciotto et al., 1989). The environmental source of $L$. pneumophila is water, where an association with free-living amoebae has been reported (Fields et al., 1989). Fourteen distinct serogroups (SGs) of the species L. pneumophila and another 33 Legionella species, also distinguishable by serotyping, have been described. Legionella species other than L. pneumophila are also found in aquatic habitats and some of them are associated with human disease (Winn, 1988).

Virulence of Legionella strains is characterized in vitro by multiplication of bacteria in human monocytes or macrophage-like cell lines at $37^{\circ} \mathrm{C}$ (Cianciotto et al., 1989). In vivo models comprise aerosol- and intraperitoneally-infected guinea pigs, and cultivation in embryonated hen eggs (Baskerville et al., 1981; Cianciotto et al., 1989; Catrenich \& Johnson, 1988; Elliott \& Johnson, 1982). Legionella isolates are also able to invade free-

Abbreviations: BCYE, buffered charcoal yeast extract; S-layer, surface layer. living amoebae at lower temperatures which is considered to be a prerequisite for their survival in aquatic habitats (Winn, 1988). There are few reports about the mechanisms involved in pathogenicity of Legionella (Cianciotto et al., 1989, 1990; Hoffman et al., 1990; Keen \& Hoffman, 1989) and on the survival mechanisms in the environment (Kilvington \& Price, 1990).

Surface structures, which are often involved in bacterial pathogenicity, have not been thoroughly described in Legionella. The chemistry of lipopolysaccharide, determining the different serogroups (Conlan \& Ashworth, 1986), has been elucidated for L. pneumophila (Sonesson et al., 1989). Capsules have not been detected (Hebert et al., 1984), but some authors report the presence of fimbriae and flagella (Chandler et al., 1980; Rodgers et al., 1980). In this report we further analysed the surface of $L$. pneumophila for crystalline surface (S) layers (Sleytr \& Messner, 1988 a) and focussed our studies on the expression of flagella in L. pneumophila and other Legionella species.

\section{Methods}

Bacterial strains. Bacterial strains used are listed in Table 1. The avirulent derivative of $L$. pneumophila Philadelphia I, XXXV, has been described elsewhere (Bender et al., 1990). The Philadelphia I strain 
Table 1. Analysis of flagellation of Legionella strains

\begin{tabular}{|c|c|c|c|}
\hline Strain & Flagellation* & $\begin{array}{c}\text { Reaction with } \\
\text { polyclonal antibodies } \dagger\end{array}$ & Reference \\
\hline $\begin{array}{l}\text { L. pneumophila, SG1 } \\
\text { Philadelphia I }\end{array}$ & + & + & ATCC 33152 \\
\hline $\begin{array}{l}\text { L. pneumophila, SG1 } \\
\text { XXXV avirulent }\end{array}$ & + & + & Bender et al. (1990) \\
\hline $\begin{array}{l}\text { L. pneumophila } \\
\mathrm{U}_{1} \mathrm{SG} 1 \text { water isolate }\end{array}$ & + & + & Bender et al. (1990) \\
\hline $\begin{array}{l}\text { L. pneumophila } \\
\mathrm{U}_{21} \text { SG1 water isolate }\end{array}$ & + & + & Bender et al. (1990) \\
\hline L. micdadei & + & + & ATCC 33218 \\
\hline L. longbeachae, SG1 & - & - & ATCC 33462 \\
\hline L. longbeachae, SG2 & + & + & ATCC 33484 \\
\hline L. hackelia, SGl & + & + & ATCC 35250 \\
\hline L. hackelia, SG2 & + & + & ATCC 35999 \\
\hline L. dumoffii & - & - & ATCC 33279 \\
\hline L. oakridgensis & - & - & ATCC 33761 \\
\hline L. feeleii. SG1 & - & _ & ATCC 35072 \\
\hline L. feeleii, SG2 & + & - & ATCC 35849 \\
\hline L. jordanis & + & - & ATCC 33623 \\
\hline
\end{tabular}

* Flagellation was determined by electron microscopy of bacteria grown at $30^{\circ} \mathrm{C}$.

$\dagger$ Determined by Western blot analysis using anti-L. pneumophila Philadelphia I flagellin antibodies (see text; cf. Fig. 4).

(ATCC 33152) has been passaged intraperitoneally in guinea pigs. Bacteria removed after the second passage from the peritoneum of the animal exhibiting symptomatic peritonitis were cultured once on buffered charcoal yeast extract (BCYE) agar and frozen. In this way fresh isolates were used for our studies. The avirulent derivative XXXV did not exhibit any infectivity after inoculation into the guinea pig peritoneum. The environmental $L$. pneumophila isolates originated from warm-water tanks. They were identified according to internationally accepted criteria (Harrison \& Taylor, 1988) and subtyped by monoclonal antibodies for determining the serogroup according to Joly et al. (1983). All other strains were obtained from the American Type Culture Collection (ATCC, Rockville, Maryland, USA). Strains were stored at $-70^{\circ} \mathrm{C}$ in $50 \%(\mathrm{v} / \mathrm{v})$ glycerol.

Media and reagents. Legionella strains were cultured on $\mathrm{BCYE}$ at $37^{\circ} \mathrm{C}$ with a $5 \% \mathrm{CO}_{2}$ atmosphere for $2-3 \mathrm{~d}$ (Edelstein, 1981) unless otherwise stated. Reagents for Legionella growth media were purchased from Oxoid. Peroxidase-conjugated anti-rabbit IgG antibodies were obtained from Dako. All other chemicals were a gift from Sigma.

Freeze etching. The bacteria were collected from the plates with a spatula loaded onto the specimen holder and frozen immediately by immersion into liquid Freon, cooled by liquid nitrogen. Freeze-etching was carried out in a Balzers BA $360 \mathrm{M}$ freeze-etching unit at $-98^{\circ} \mathrm{C}$ $(175 \mathrm{~K})$ and the samples were etched for $1.5 \mathrm{~min}$. After unidirectional shadowing with platinum/carbon and backing with carbon, the replicas were cleaned in $30 \%$ chromium oxide for $2 \mathrm{~d}$ at room temperature. The micrographs were taken with a Philips EM 301 electron microscope (Messner et al., 1984).

Electron microscopy. Bacteria grown on BCYE agar plates were carefully resuspended in distilled water on the agar plate and a drop of the suspension was directly applied to Formvar-coated copper grids. After sedimentation of the bacteria and removal of remaining fluid, the samples were shadowed with platinum/palladium and examined with a Zeiss 10A transmission electron microscope.
Isolation of flagella and SDS-PAGE. Bacteria grown on BCYE agar plates were resuspended in cold $50 \mathrm{mM}$-Tris $/ \mathrm{HCl}(\mathrm{pH} \mathrm{6.8)} 0.02 \%$ $\mathrm{NaN}_{3}$. Cell appendages were removed by mixing the suspension in a Sorvall blender on ice to avoid autolysis of the bacteria. Mixing was carried out for $5 \mathrm{~min}$ three times with $5 \mathrm{~min}$ pauses between each procedure. Cells were removed by centrifugation and $\left(\mathrm{NH}_{4}\right)_{2} \mathrm{SO}_{4}$ was added to the supernatant to $15 \%$ saturation. Proteins were precipitated by stirring slowly overnight at $4{ }^{\circ} \mathrm{C}$. After centrifugation at $30000 \mathrm{~g}$ the protein pellet was resuspended in $\mathrm{Tris} / \mathrm{HCl}$ buffer and stored at $4{ }^{\circ} \mathrm{C}$.

SDS-PAGE was performed according to the method of Laemmli (1970). Isolated flagella or whole bacterial cells were boiled for $10 \mathrm{~min}$ in Laemmli buffer and applied to the gels.

Preparation of polyclonal antibodies against whole bacteria. $L$. pneumophila ATCC 33152 cells grown on BCYE agar plates were suspended in $10 \mathrm{~mm}-\mathrm{PBS}(\mathrm{pH} 7.5)$ and immediately treated with $1 \%$ $(\mathrm{v} / \mathrm{v})$ formalin for $12 \mathrm{~h}$. After washing, the bacteria $\left(10^{9} \mathrm{ml}^{-1}\right)$ were emulsified in equal volume of incomplete Freund's adjuvant (Difco). Two rabbits received approximately $1 \mathrm{ml}$ emulsion subcutaneously in four to six sites in the scapular region of the back. After 4 weeks the procedure was repeated with live L. pneumophila suspended in PBS. Two weeks after the last injection, rabbits were exsanguinated. Serum was stored at $-20^{\circ} \mathrm{C}$.

Affinity purification of anti-flagellin polyclonal antibodies. Antiflagellin specific polyclonal antibodies were purified using the antiserum prepared against whole $L$. pneumophila Philadelphia I bacteria and the flagellin antigen was immobilized on nitrocellulose, as described by Sambrook et al. (1989).

Western blot analysis. Western blot analysis was performed according to the method of Towbin et al. (1979). Bacteria grown on BCYE were resuspended in distilled water. The $\mathrm{OD}_{600}$ values of the suspensions were adjusted to 0.8 . The suspension $(1 \mathrm{ml})$ was centrifuged and the bacteria were resuspended in $100 \mu$ of Laemmli buffer (Laemmli, 1970). After boiling for $5 \mathrm{~min}, 10 \mu \mathrm{l}$ were loaded on to an SDS-PAGE 


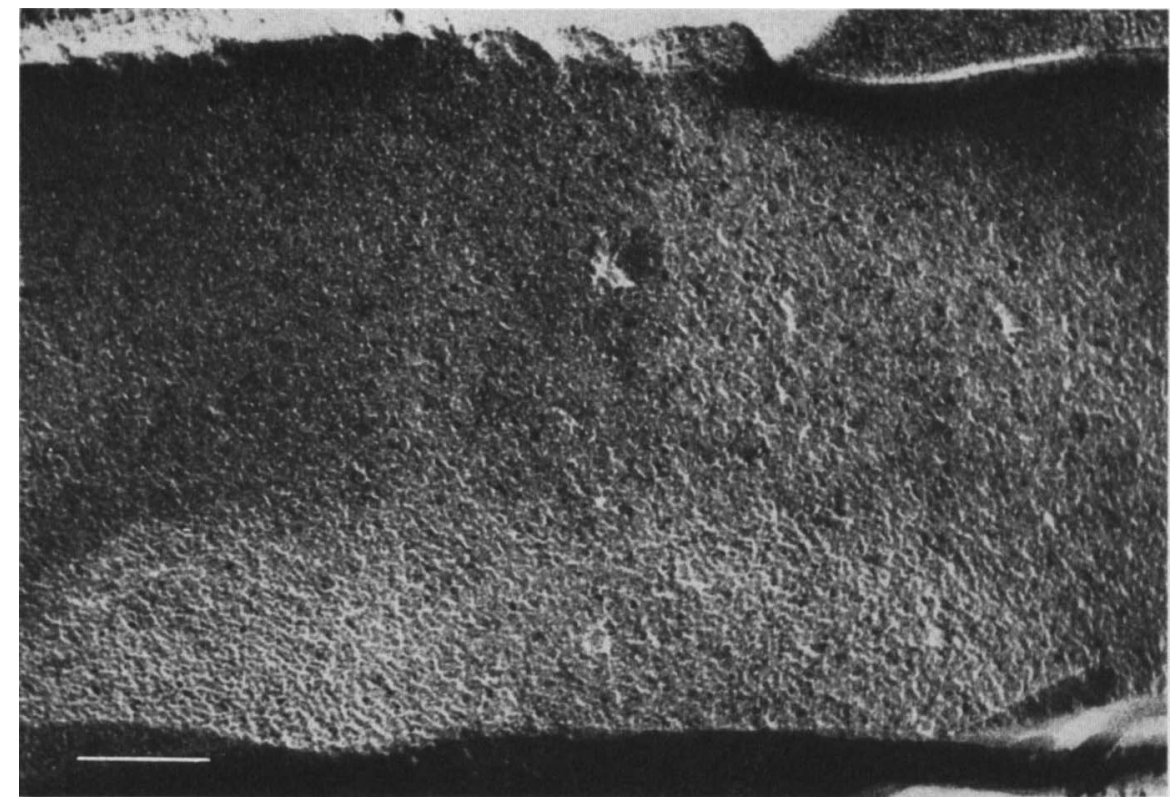

Fig. 1. Electron micrograph of a freezeetched specimen of $L$. pneumophila Philadelphia I. Bar, $0.05 \mu \mathrm{m}$. gel. As a control, approximately $0.5 \mu \mathrm{g}$ of isolated flagella were applied. For the detection of bound antibodies, peroxidase-conjugated swine anti-rabbit $\operatorname{IgG}$ antibodies were used. The colour reaction was developed using 4,1-chloronaphthol.

\section{Results}

Surface examination of L. pneumophila by electron microscopy

To determine if $L$. pneumophila had crystalline S-layers, samples of four $L$. pneumophila isolates, including strain Philadelphia I, grown at $37^{\circ} \mathrm{C}$ were prepared by freezeetching and examined by electron microscopy. All the strains investigated had a smooth surface, indicating the absence of S-layers (Fig. 1). Examination of further samples prepared by platinum/palladium shadowing for detection of cell appendages, revealed the presence of flagella (Fig. 2a), while other organelles such as fimbriae were not detected. Most bacteria carried one polar flagellum, but non-flagellated cells were also observed.

\section{Flagellation of L. pneumophila isolates and other Legionella species}

A $47 \mathrm{kDa}$ band, which represents the flagellum subunit, was present after SDS-PAGE of flagella isolated from $L$. pneumophila Philadelphia I (Fig. 3a, lane 2; cf. Elliott \& Johnson, 1981). To detect anti-flagellin antibodies in an anti- $L$. pneumophila antiserum prepared against whole bacteria, a Western blot was performed with whole-cell
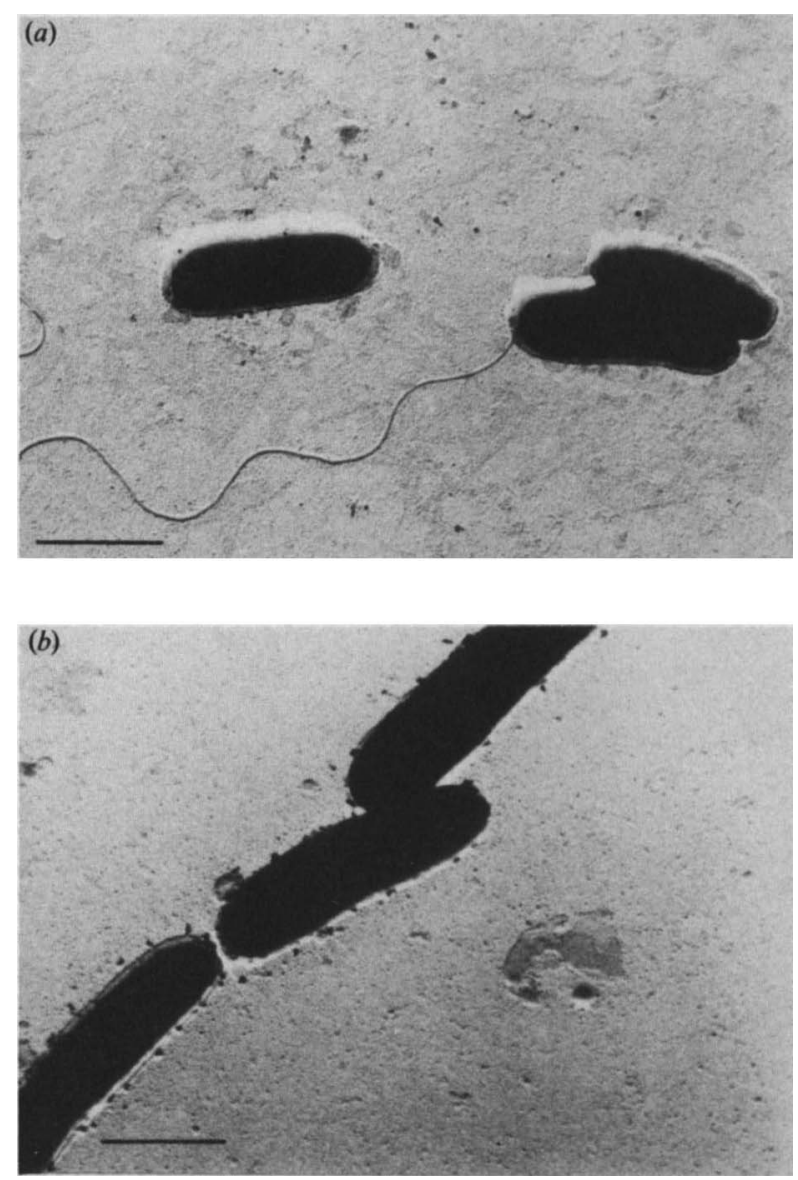

Fig. 2. Electron micrographs of $L$. pneumophila Philadelphia I grown at (a) 30 and $(b) 41^{\circ} \mathrm{C}$. The samples were shadowed with platinum/palladium. Bars, $0.5 \mu \mathrm{m}$. 


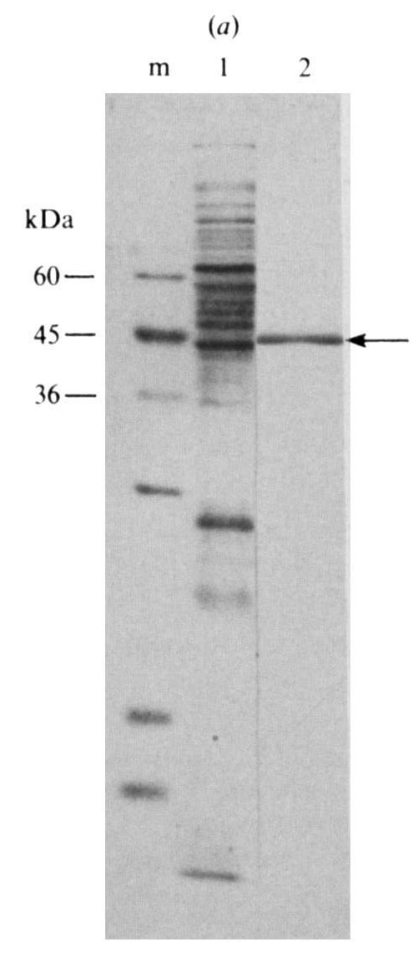

(b)

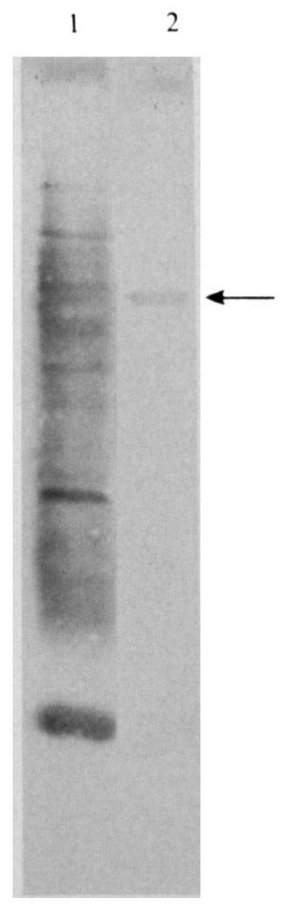

Fig. 3. (a) SDS-PAGE and (b) Western blot analysis of whole-cell extracts of $L$. pneumophila Philadelphia I (lane 1) and isolated flagella of this strain (lane 2), using antiserum prepared against whole $L$. pneumophila Philadelphia I bacteria. The arrows indicate the $47 \mathrm{kDa}$ flagellin band. Molecular mass standards are shown in lane $\mathrm{m}$.

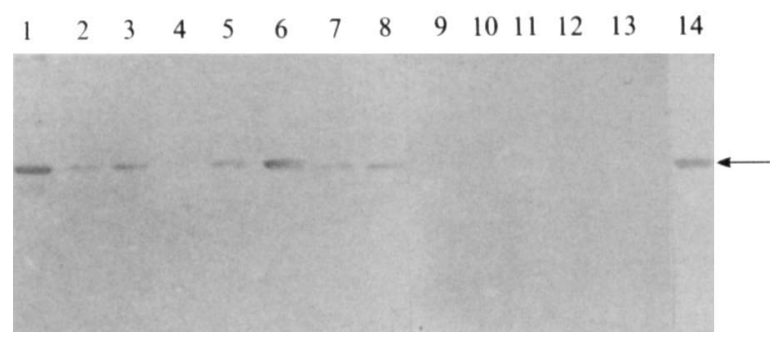

Fig. 4. Western blot analysis using affinity purified anti-Philadelphia I flagellin antibodies of whole-cell extracts of strains grown at $30^{\circ} \mathrm{C}$. Lanes: (1) L. pneumophila Philadelphia I: (2) L. pneumophila $\mathrm{U}_{1} \mathrm{SG}_{1}$; (3) L. pneumophila $\mathrm{U}_{21} \mathrm{SG}_{6}$; (4) L. longbeachae $\mathrm{SG} 1$; (5) L. longbeachae SG2; (6) L. micdadei; (7) L. hackelia SG1; (8) L. hackelia SG2; (9) L. oakridgensis; (10) L. dumoffii ; (11) L. jordanis; (12) L. feeleii SG1 ; (13) L. feeleii SG2; (14) isolated flagella. The arrow indicates the $47 \mathrm{kDa}$ flagellin band.

extracts and isolated flagella of the Philadelphia I strain. The flagellin subunits reacted with the serum (Fig. $3 b$, lane 2), indicating a high titre of anti-flagellin antibodies. The reaction with the cell extract (Fig. $3 a$, lane 1) appeared as a smear (Fig. $3 b$, lane 1). Starting with this serum, anti-flagellin antibodies were affinity purified using antigen immobilized on nitrocellulose. Flagellation was further analysed in various $L$. pneumophila isolates
Table 2. Percentage of flagellated L. pneumophila within a bacterial population grown at different temperatures

Percentage of flagellated bacteria was determined by electron microscopy. Approximately 400 bacteria were observed at each temperature.

\begin{tabular}{cccr}
\hline \hline & \multicolumn{3}{c}{ Percentage of flagellated bacteria at $\left({ }^{\circ} \mathrm{C}\right):$} \\
\cline { 2 - 4 } Strain & 30 & 37 & 41 \\
\hline $\begin{array}{c}\text { Philadelphia I } \\
\text { virulent }\end{array}$ & $60-70$ & $20-30$ & $<5$ \\
$\begin{array}{c}\text { Philadelphia I } \\
\text { XXXV, avirulent }\end{array}$ & $60-70$ & $20-30$ & $<5$ \\
\hline \hline
\end{tabular}

and other Legionella species. The strains were first examined by electron microscopy. All strains, with the exception of $L$. longbeachae SG1, $L$. dumoffii, $L$. oakridgensis and L. feeleii SG1, were flagellated (Table 1). The use of polyclonal anti-flagellin antibodies in Western blot analysis of whole-cell extracts of the strains grown at $30^{\circ} \mathrm{C}$ (Fig. 4) produced a positive reaction with the L. pneumophila water isolates (U1SG1 and U21SG6; Fig. 4, lanes 2 and 3, respectively), L. longbeachae (SG2; Fig. 4, lane 5), L. micdadei (Fig. 4, lane 6), L. hackelia (SG1 and 2; Fig. 4, lanes 7 and 8, respectively) which all exhibited a band of approximately the same size as the Philadelphia I strain. For the remaining strains no reaction was observed (Fig. 4, lanes 4 and 9-13).

\section{Temperature-dependent expression of flagella in L. pneumophila}

The flagellation of L. pneumophila Philadelphia I and the avirulent variant $\mathrm{XXXV}$ was evaluated by electron microscopy after growing the strains at 30,37 and $41{ }^{\circ} \mathrm{C}$. In both strains the percentage of flagellated bacteria decreased with increasing growth temperature, i.e. at $30{ }^{\circ} \mathrm{C}$ nearly two-thirds of the bacteria were flagellated, while at $37^{\circ} \mathrm{C}$ about one-third of the population displayed flagella and at $41^{\circ} \mathrm{C}$ only a very small proportion of the bacterial cells $(<5 \%)$ had flagella (Fig. $2 b$; Table 2). There was no marked difference between the virulent and avirulent variants.

The effect of temperature on flagellation was further analysed by Western blots. The antibodies were tested using whole-cell extracts of the Philadelphia I strain and of the avirulent derivative XXXV grown at 30,37 and $41{ }^{\circ} \mathrm{C}$. The purified antibodies reacted specifically with the $47 \mathrm{kDa}$ flagellin protein subunit (cf. Fig. 3) in both strains when grown at $30^{\circ} \mathrm{C}$ ( Fig. $5 a$, lanes 3 and 4), but no reaction was observed with extracts obtained from bacteria cultivated at $37^{\circ} \mathrm{C}$ (Fig. $5 a$, lanes 5 and 6). At a 


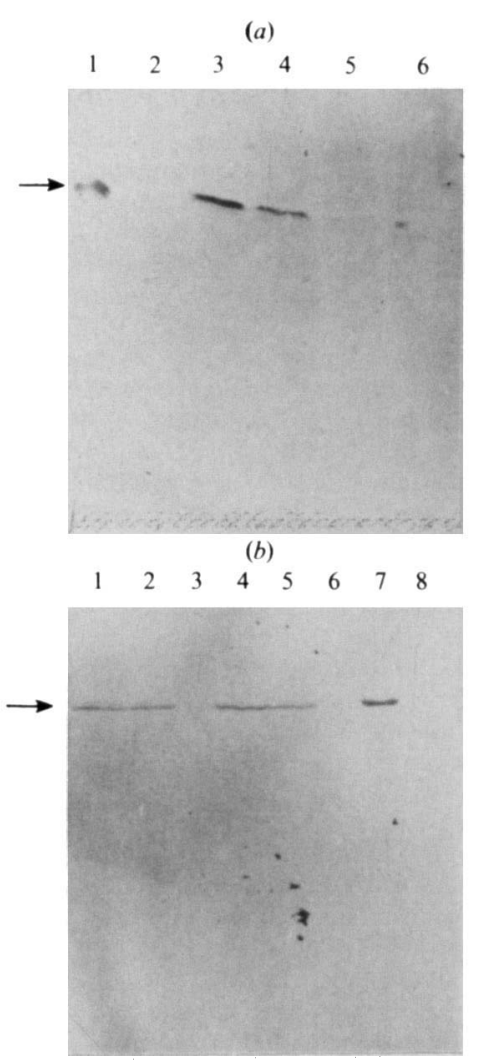

Fig. 5. Western blot analysis of whole cell extracts of $L$. pneumophila Philadelphia I and an avirulent derivative (XXXV) using purified antiflagellin antibodies. Strains were grown at different temperatures as indicated. (a) Lanes: (1) isolated flagella; (2) E. coli $536\left(37^{\circ} \mathrm{C}\right)$; (3) $L$. pneumophila Philadelphia I $\left(30^{\circ} \mathrm{C}\right)$; (4) L. pneumophila XXXV $\left(30^{\circ} \mathrm{C}\right)$; (5) L. pneumophila Philadelphia I $\left(37^{\circ} \mathrm{C}\right)$; (6) L. pneumophila XXXV $\left(37^{\circ} \mathrm{C}\right)$. (b) Lanes: (1) L. pneumophila Philadelphia I ( $\left.30^{\circ} \mathrm{C}\right)$; (2) L. pneumophila Philadelphia I $\left(37^{\circ} \mathrm{C}\right)$; (3) L. pneumophila Philadelphia I $\left(41^{\circ} \mathrm{C}\right)$; (4) L. pneumophila XXXV $\left(30^{\circ} \mathrm{C}\right)$; (5) L. pneumophila XXXV $\left(37^{\circ} \mathrm{C}\right)$; (6) L. pneumophila XXXV $\left(41^{\circ} \mathrm{C}\right)$; (7) isolated flagella; (8) E. coli $536\left(37^{\circ} \mathrm{C}\right)$. Anti-flagellin antibody concentration in $(b)$ was four times higher than in $(a)$. Arrows indicate the $47 \mathrm{kDa}$ flagellin band.

fourfold higher concentration of antibodies (Fig. $5 b$ ) flagella subunits could be detected in the strains grown at $37^{\circ} \mathrm{C}$, (Fig. $5 b$, lanes 2 and 5) but not in extracts obtained from cultures which were grown at $41{ }^{\circ} \mathrm{C}$ (Fig. $5 b$, lanes 3 and 6). These data are in good agreement with those of the electron microscopic examination (Table 2). Flagellated Escherichia coli strain 536 (O6:K15:H31, see Hacker \& Goebel, 1987) used as control (Fig. 5a, lane 2 and Fig. $5 b$, lane 8 ) produced no reaction with the purified antibodies. Additionally, the other strains that reacted with the polyclonal antiserum, when grown at $30^{\circ} \mathrm{C}$ (cf. Fig. 4), displayed a weaker or no reaction after cultivation at $37^{\circ} \mathrm{C}$ (data not shown), arguing for a temperature-regulated expression of flagella also in these Legionella strains.

\section{Discussion}

Surface structures of Gram-negative cells, such as capsules, lipopolysaccharides and cell appendages including fimbriae and flagella play a major role in bacterial pathogenicity and in the ability of strains to survive in the environment (Isenberg, 1988; Finlay \& Falkow, 1989). In L. pneumophila the prominent cellsurface structures were flagella consisting of protein subunits of $47 \mathrm{kDa}$ and organized as monotrichous polar appendages. Freeze-etching studies did not reveal a crystalline S-layer, although such proteinaceous surface structures can be found in a variety of bacteria (Sleytr \& Messner, $1988 b$ ). We were also unable to detect fimbriae which have been described by Chandler et al. (1980) and Rodgers et al. (1980). The failure to detect fimbriae might be due to differences in the growth conditions used, as Rodgers et al. (1980) reported the presence of fimbriae after cultivation in broth or on enriched blood agar.

The first reports on flagella in $L$. pneumophila came from Chandler et al. (1980) and from Elliott \& Johnson (1981, 1982). The latter authors further described a difference in the expression of flagella in virulent and avirulent variants of $L$. pneumophila Philadelphia 2 and an influence of the growth medium on flagella production. In contrast to these findings, we could not detect any difference between virulent and avirulent derivatives of the Philadelphia I strain, when grown on BCYE agar. Using polyclonal anti-flagellin antibodies, we demonstrated that $L$. pneumophila water isolates and some other Legionella species produce proteins of approximately the same size as the $L$. pneumophila Philadelphia I flagellin subunit. This suggests that flagella may be conserved among some species of the genus Legionella, which are distantly related on the DNA level (Brenner, 1986). Other Legionella species did not display proteins reacting with the anti-flagellin antibodies of $L$. pneumophila, although flagellation could be demonstrated by electron microscopy.

Surface structures, e.g. fimbriae and capsules often show a strong temperature-dependent expression (Göransson \& Uhlin, 1984; Schmoll et al., 1990; for review see Maurelli, 1989). We therefore investigated the influence of growth temperature on flagella expression in L. pneumophila. At higher temperatures, production of flagella was reduced or nearly abolished. Using electron microscopy, we observed that the overall decrease in the number of flagella within a population was due to a reduced percentage of flagellated bacteria. Temperaturedependent expression of flagella has also been reported for Listeria monocytogenes (Peel et al., 1988), and transition from $\mathrm{Flag}^{+}$to $\mathrm{Flag}^{-}$has been described for Campylobacter jejuni (Aguero-Rosenfeld et al., 1990). 
It is interesting to speculate whether flagellation of Legionella has an influence on virulence or survival ability in the environment. Flagella have been shown to contribute to the pathogenicity of Salmonella (Finlay \& Falkow, 1989) and Pseudomonas aeruginosa (Drake \& Montie, 1988). The fact that avirulent variants of $L$. pneumophila do not differ according this phenotype suggests, that flagella are not important for virulence as also suggested by Elliott \& Johnson (1982). Properties of pathogenic relevance are generally expressed at $37^{\circ} \mathrm{C}$ while penetration into amoebae and other processes important for the survival of Legionella in the environment may occur at lower temperatures. Flagella, however, were expressed to a greater extent at lower temperatures, suggesting that flagellation might contribute to environmental survival processes rather than to pathogenicity. The precise role of flagellation in the biology of Legionella remains to be evaluated.

The authors wish to thank W. Ehret (München) for sending the environmental L. pneumophila strains and $\mathbf{M}$. Wuenscher (Würzburg) for critical reading of the manuscript. S. Gintschel (Würzburg) and A. Scheberl (Wien) are gratefully acknowledged for excellent technical assistance. We thank L. Bender (Würzburg) for advice in electron microscopy and $\mathbf{H}$. Kurz (Würzburg) for editorial assistance. The work was supported by the Bundesministerium für Forschung und Technologie (BMFT O1Ki 8829; 8812).

\section{References}

Aguero-Rosenfeld, M. E., Yang, X.-H. \& Nachamkin, I. (1990). Infection of adult syrian hamsters with flagellar variants of Campylobacter jejuni. Infection and Immunity 58, 2214-2219.

Baskerville, A., Fitzgeorge, R. B., Broster, M., HAMbleton, P. \& DENNIS, P. J. (1981). Experimental transmission of Legionnaires' disease by exposure to aerosols of Legionella pneumophila. Lancet ii, 1389-1390.

Bender, L., Ott, M., Marre, R. \& Hacker, J. (1990). Genome analysis of Legionella spp. by orthogonal field alternation gel electrophoresis (OFAGE). FEMS Microbiology Letters 72, 253-258.

BRENNER, D. J. (1986). Classification of Legionellaceae: current status and remaining questions. Israel Journal of Medical Sciences 22, 620632.

Chandler, F. W., Roth, I. L., Callaway, C. S., Bump, J. L., ThOMASON, B. M. \& WEAVER, R. E. (1980). Flagella on Legionnaires disease bacteria. Annals of Internal Medicine 93, 711-714.

Catrenich, C. E. \& Johnson, W. (1988). Virulence conversion of Legionella pneumophila: a one way phenomenon. Infection and Immunity 56, 3121-3125.

Cianciotto, N., Eisenstein, B. I., Engleberg, N. C. \& Shuman, H. (1989). Genetics and molecular pathogenesis of Legionella pneumophila, an intracellular parasite of macrophages. Molecular Biology and Medicine 6, 409-424.

Cianciotto, N., Eisenstein, B. I., Mody, C. H. \& Engleberg, N. C. (1990). A mutation in the mip gene results in an attenuation of Legionella pneumophila virulence. Journal of Infectious Diseases 162, 121-126.

Conlan, J. W. \& Ashworth, L. W. (1986). The relationship between the serogroup antigen and lipopolysaccharide of Legionella pneumophila. Journal of Hygiene 96, 39-48.
Drake, D. \& Montie, T. C. (1988). Flagella, motility, and invasive virulence of Pseudomonas aeruginosa. Journal of General Microbiology 134, 43-52.

EDELSTEIN, P. H. (1981). Improved semiselective medium for isolation of Legionella pneumophila from contaminated clinical and environmental specimens. Journal of Clinical Microbiology 14, 298-303.

ELLIOTT, J. A. \& JoHNSON, W. (1981). Immunological and biochemical relationships among flagellae isolated from Legionella pneumophila serogroups 1, 2 and 3. Infection and Immunity 33, 602-610.

ElliotT, J. A. \& Johnson, W. (1982). Virulence conversion of Legionella pneumophila serogroup 1 by passage in guinea pigs and embryonated eggs. Infection and Immunity 35, 943-946.

Fields, B. S., Sanden, G. N., Barbaree, J. M., Morrill, W. E., Wadowsky, R. M., White, E. H. \& Feeley, J. C. (1989). Intracellular multiplication of Legionella pneumophila in amoebae isolated from hospital hot water tanks. Current Microbiology 18, 131137.

Finlay, B. B. \& Falkow, S. (1989). Salmonella as an intracellular parasite. Molecular Microbiology 3, 1833-1841.

GöRANSSON, M. \& Uhlin, B. E. (1984). Environmental temperature regulates transcription of a virulence pili operon in E. coli. EMBO Journal 3, 2885-2888.

HACKer, J. \& Goebel, W. (1987). Mechanisms and methods for analysing pathogenicity. Swiss Biotech 5, 21-31.

Harrison, T. G. \& TAYlor, A. G. (Editors) (1988). A Laboratory Manual for Legionella. Chichester: Wiley.

Hebert, G. A., Callaway, C. S. \& Ewing, E. P., JR. (1984) Comparison of Legionella pneumophila, L. micdadei, L. bozemanii and L. dumoffii by transmission electron microscopy. Journal of Clinical Microbiology 19, 116-121.

Hoffman, P. S., Houston, L. \& Butler, C. A. (1990). Legionella pneumophila htpAB heat shock operon: nucleotide sequence and expression of the 60 kilodalton antigen in L. pneumophila infected HeLa cells. Infection and Immunity 58, 3380-3387.

ISENBERG, H. D. (1988). Pathogenicity and virulence: another view. Clinical Microbiology Reviews 1, 40-53.

Joly, I. R., Chen, Y. Y. \& RamSAY, D. (1983). Serogrouping and subtyping of Legionella pneumophila with monoclonal antibodies. Journal of Clinical Microbiology 18, 1040-1046.

KeEN, M. G. \& Hoffman, P. S. (1989). Characterization of Legionella pneumophila extracellular protease exhibiting hemolytic and cytotoxic activities. Infection and Immunity 57, 732-738.

Kilvington, S. \& PRICE, J. (1990). Survival of Legionella pneumophila within cysts of Acanthamoeba polyphaga following chlorine exposure. Journal of Applied Bacteriology 68, 519-525.

LAEMMLI, U. K. (1970). Cleavage of structural proteins during the assembly of the head of bacteriophage T4. Nature, London 227, 680685 .

MAUReLli, A. T. (1989). Temperature regulation of virulence genes in pathogenic bacteria: a general strategy for human pathogens? Microbial Pathogenesis 7, 1-10.

Messner, P., Hollaus, F. \& Sleytr, U. B. (1984). Paracrystalline cell wall surface layers of different Bacillus stearothermophilus strains. International Journal of Systematic Bacteriology 34, 202-210.

Peel, M., Donachie, W. \& Shaw, A. (1988). Temperature-dependent expression of flagella of Listeria monocytogenes. Journal of General Microbiology 134, 2171-2178.

Rodgers, F. G., Greaves, P. W., Macrae, A. D. \& Lewis, M. J. (1980). Electron microscopic evidence of flagella and pili on Legionella pneumophila. Journal of Clinical Pathology 33, 1184-1188.

SambrooK, J., Fritsch, E. F. \& Maniatis, T. (1989). Molecular Cloning : a Laboratory Manual, 2nd Edn. Cold Spring Harbor NY: Cold Spring Harbor Laboratory.

SCHMOLL, T., OTT, M., OUdEGA, B. \& HACKeR, J. (1990). Use of a wildtype gene fusion to determine the influence of environmental conditions on expression of the $\mathrm{S}$ fimbrial adhesin in an Escherichia coli pathogen. Journal of Bacteriology 172, 5103-5111.

SleytR, U. B. \& Messner, P. (1988a). Crystalline surface layers on bacteria. In Crystalline Bacterial Cell Surface Layers, pp. 160-186. Edited by U. B. Sleytr, P. Messner, D. Pum \& M. Sara. Berlin: Springer Verlag. 
SLeYtr, U. B. \& MesSNER, P. (1988b). Crystalline surface layers in prokaryotes. Journal of Bacteriology 170, 2891-2897.

Sonesson, A., Jantzen, E., BRYN, K., Larsson, L. \& ENG, J. (1989). Chemical composition of a lipopolysaccharide from Legionella pneumophila. Archives of Microbiology 153, 72-78.
Towbin, H., Staehelin, T. \& Gordon, J. (1979). Electrophoretic transfer of proteins from polyacrylamide gels to nitrocellulose sheets: procedure and some applications. Proceedings of the National Academy of Sciences of the United States of America 76, 4350-4354. WINN, W. C., JR (1988). Legionnaires disease : a historical perspective. Clinical Microbiology Reviews 1, 60-81. 